\title{
Prediction of pressure drop through packed beds of granular materials: influence of moisture reduction and air velocity
}

\author{
Previsão de queda de pressão em leitos empacotados com \\ materiais granulares: influência da redução da umidade e \\ velocidade do ar
}

\author{
Heitor Otacílio Nogueira Altino ${ }^{1}$ (D), Maria do Carmo Ferreira ${ }^{1 *}$ (i) \\ ${ }^{1}$ Universidade Federal de São Carlos (UFSCar), Departamento de Engenharia Química, São Carlos/SP - Brasil \\ *Corresponding Author: Maria do Carmo Ferreira, Universidade Federal de São Carlos (UFSCar), Departamento \\ de Engenharia Química, Rodovia Washington Luís, km 235, CEP: 13565-905, São Carlos/SP - Brasil, \\ e-mail: mariaf@ufscar.br
}

Cite as: Altino, H. O. N., \& Ferreira, M. C. (2019). Prediction of pressure drop through packed beds of granular materials: influence of moisture reduction and air velocity. Brazilian Journal of Food Technology, 22, e2018228. https://doi.org/10.1590/1981-6723.22818

\begin{abstract}
The influence of the moisture content of the solids on the pressure drop through packed beds of soy, barley, lentils and oats was investigated. The properties of the grains and the packed beds were determined varying the moisture contents of the solids between the equilibrium moisture content and $0.24 \mathrm{~g} \mathrm{~g}^{-1}$ (mass of water per mass of dry solid). The pressure drops were measured as a function of the aeration velocity under different moisture contents of the solids. It was observed that a reduction in the moisture content caused a decrease in the particle dimensions but did not affect their shape. Due to the reduction in size caused by the moisture removal, the packed beds become denser and less permeable to the airflow, resulting in an increase in the pressure drop. In the moisture range investigated, the pressure drops increased by more than $39 \%$ for lentils, soy and barley, and by about $24 \%$ for oats, indicating that the energy consumption during aeration could rise significantly. The parameters of the Forchheimer's equation were modified to take into account the influence of the moisture content of the solids on the pressure drops. For each particle, empirical equations were proposed and shown to be adequate to accurately predict the pressure drop of the packed beds as a function of the moisture content and aeration velocity.
\end{abstract}

Keywords: Permeability; Grain storage; Cereals; Aeration; Shrinkage; Tortuosity.

\section{Resumo}

Neste estudo foi investigada a influência da umidade do sólido sobre a queda de pressão em leitos fixos de soja, cevada, lentilha e aveia. As propriedades dos grãos e do leito foram determinadas variando-se a umidade dos sólidos entre o valor de equilíbrio até $0,24 \mathrm{~g} \mathrm{~g}^{-1}$ (massa de água por massa de sólido seco). As quedas de pressão nos leitos foram medidas em função da velocidade de aeração para diferentes níveis de umidade do sólido. Foi observado que uma redução no teor de umidade causou uma diminuição nas dimensões das partículas, mas 
não afetou sua forma. Devido à redução de tamanho provocada pela remoção da umidade, os leitos tornaram-se mais densos e menos permeáveis ao escoamento de ar, resultando em aumento na queda de pressão. Na faixa de umidade investigada, as quedas de pressão aumentaram em mais de 39\% para a lentilha, soja e cevada, mas apenas em $24 \%$ para a aveia, indicando que o consumo de energia na aeração pode aumentar significativamente. Os parâmetros da equação de Forchheimer foram modificados para considerar a influência do teor de umidade do sólido nas quedas de pressão. Para cada partícula, equações empíricas foram propostas e mostraram-se adequadas para prever com boa precisão a queda de pressão dos leitos em função do conteúdo da umidade e velocidade de aeração.

Palavras-chave: Permeabilidade; Armazenamento de grãos; Cereais; Aeração; Encolhimento; Tortuosidade.

\section{Introduction}

Grains and cereals are important staple foods that are cropped seasonally and have to be properly processed and stored to meet the market demand throughout the year. According to Food and Agriculture Organization of the United Nations (2018) statistics, cereal use in the world is forecast to be 2,641 million tonnes in 2018/19, and the estimated production will not be sufficient to meet this expected use, therefore the deficit must be supplied by accumulated stocks. The importance of storage has grown significantly as a result of the increase in volumes traded and the rise in worldwide food demand. Aeration in silos is commonly used to improve the storability of grains, because forced ventilation helps to keep uniform temperatures throughout the silo, and contributes to avoiding moisture migration and removing the odours of the stored grain masses, and can also be used to apply fumigation (Khatchatourian \& Savicki, 2004; Khatchatourian et al., 2017).

The static pressure requirements of the fan used for aeration, drying or cooling of a packed bed of grains, is determined by the resistance of the packed grains to the airflow. The pressure drop across a homogeneous packed bed of granular material can be predicted by Forchheimer's equation, given by (Coulson \& Richardson, 2002):

$\frac{\Delta P}{L}=\frac{\mu}{\kappa} U+\frac{c \rho}{\sqrt{\kappa}} U^{2}$

where $U$ is the aeration velocity; $\Delta P$ is the pressure drop though the packed bed; $L$ is the bed height; $\mu$ is the air dynamic viscosity; $\rho$ is the air density; $\kappa$ is the Darcy's permeability; and $c$ the inertial resistance factor.

Although Equation 1 establishes a simple relationship between the pressure drop and the aeration velocity, the challenges involved in using it are that the permeability and inertial resistance factor are parameters dependent on the size and shape of the particles as well as on structural properties of the packed bed, such as bed porosity (German, 1989). Darcy's permeability can be interpreted as a measure of the resistance to flow offered by the porous medium. It is associated with the energy loss due to viscous flow and fluid-particle friction during flow through the porous medium, and is a characteristic of the porous structure. The inertial factor is associated with the energy loss under high-velocity flow and is enhanced by turbulence and bed tortuosity (German, 1989). Since these parameters are not easy to determine, many empirical or semi-theoretical relationships have been proposed to estimate the pressure drops through packed beds composed of either grains/seeds or particles with irregular size distribution (Park et al., 2018; Cruz et al., 2014; Li \& Sokhansanj, 1994; Matthies \& Petersen, 1974; Shedd, 1953; Yang $\&$ Williams, 1990). However in most of these studies, the effect of the moisture content of the solids on the pressure drop was neglected, but this moisture content can vary significantly during processing and storage. In food grains, variation in moisture content can lead to changes in particle size and shape that could affect the structural properties of the packed bed and modify the pressure drops (Felizardo \& Freire, 2018; Górnicki $\&$ Kaleta, 2015; Kobus et al., 2011). In addition, assessing how the grain dimensions change with moisture content is important because the variation in their volume and weight due to shrinkage has a relevant impact 
on transportation and storage costs, particularly in a country with a recognized deficit of silos, like Brazil (Rabello, 2018; Bala, 2016).

The purpose of this study was to investigate the influence of the moisture content of the solids on the pressure drops through packed beds of four widely consumed staple grains, namely soy, barley, lentils and oats, with moisture contents ranging from the equilibrium moisture up to $0.24 \mathrm{~g} . \mathrm{g}^{-1}$. The linear dimensions, surface area, volume, sphericity and density of the particles were determined as a function of the moisture content, as well as the porosity and bulk density of the packed beds. The parameters of Equation $1, \kappa$ and $c$, were estimated from the values measured for $\Delta P$ and the effect of the moisture content of the solids on $\Delta P$ was evaluated. Finally, empirical equations were proposed to take into account the influence of moisture on the values for $\kappa$ and $c$ of each grain, thus providing accurate equations to estimate $\Delta P / L$ through the beds of grains.

\section{Material and methods}

\subsection{Particulate materials}

The materials were selected to cover different particle shapes and sizes, namely: soy (Glycine max L.), green lentils (Lens culinaris), barley (Hordeum vulgare L.) and oats (Avena sativa). The dehydrated grains were purchased from a local market in São Carlos, SP, Brazil. Spherical alumina particles (type F-200) were provided by Alcoa ${ }^{\circ}$. Alumina particles have a porous structure, diameter of $3.2 \mathrm{~mm}$, surface area of $32 . \mathrm{mm}^{2}$, volume of $17.3 \mathrm{~mm}^{3}$ and sphericity close to 1.0 . As the water is absorbed mainly by the internal pores, the particle dimensions and shape do not change with moisture content. For these reasons, they were included in this study to serve as a standard particulate for comparison.

The initial moisture contents of the biological products ranged from 0.091 to $0.138 \mathrm{~g} . \mathrm{g}^{-1}$. The grains were either moistened or further dried to reach the specified moisture content levels $(X)$ for the experiments, namely $0.24,0.16,0.09 \mathrm{~g} \mathrm{~g}^{-1}$. and the equilibrium moisture $\left(x^{*}\right)$, which is the moisture achieved by each grain after drying at $50{ }^{\circ} \mathrm{C}$ in a hot-air drying oven for $72 \mathrm{~h}\left(\mathrm{TE}-394 / 1\right.$, Tecnal $\left.{ }^{\circledR}\right)$. The materials were placed in a desiccator until reaching ambient temperature and then stored in sealed packages at $4{ }^{\circ} \mathrm{C}$. The particles were moistened by inserting $150 \mathrm{~g}$ of sample into polyethylene packages, adding the necessary amount of deionized water and finally storing the sealed packages at $4{ }^{\circ} \mathrm{C}$ for $48 \mathrm{~h}$. The moisture content was measured by a gravimetric method after drying the samples in a hot-air drying oven (TE-39 4/1, Tecnal ${ }^{\circledR}$ ) at $105^{\circ} \mathrm{C}$ for $24 \mathrm{~h}$.

\subsection{Particle characterization}

The dimensions of the biological grains were determined assuming a triaxial spheroid shape (Figure 1). The lengths $\left(L_{p}\right)$ and widths $\left(W_{p}\right)$ of 60 particles were measured using an image analysis technique with a Sony ${ }^{\circledR}$ LT26i device and Image-Pro Plus ${ }^{\circledR} 6.0$ software. The thickness $\left(T_{p}\right)$ was measured using a digital caliper. The mean diameter $\left(D_{m}\right)$, volume $\left(V_{e}\right)$, surface area $\left(A_{e}\right)$ and sphericity $(\varphi)$ of the particles were calculated using Equations 2-5 (Mohsenin, 1970) and the volume $\left(V_{s}\right)$ and surface area $\left(A_{s}\right)$ were calculated using Equations 6 and 7. The apparent density $\left(\rho_{a}\right)$ was measured in triplicate by liquid pycnometry using toluene $\left(99.5 \%\right.$, Dinâmica $\left.{ }^{\circledR}\right)$ and the diameter $\left(D_{s}\right)$ of 60 alumina particles measured using a digital calliper. 


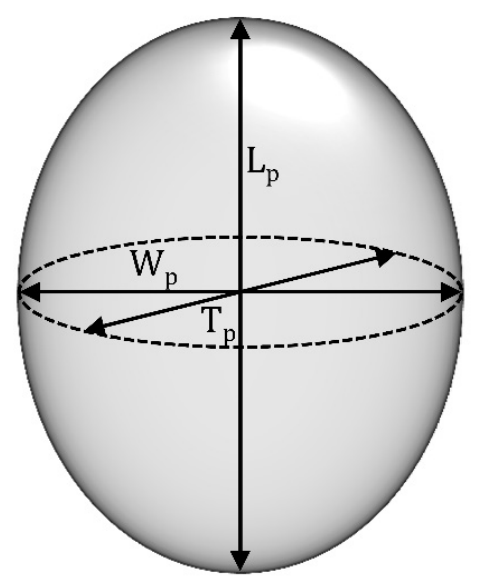

Figure 1. Dimensions of a triaxial spheroid particle, thickness $\left(T_{p}\right)$, length $\left(L_{p}\right)$ and width $\left(W_{p}\right)$.

$$
\begin{aligned}
& D_{m}=\pi\left(W_{p} L_{p} T_{p}\right)^{1 / 3} \\
& V_{e}=\frac{\pi W_{p} L_{p} T_{p}}{6} \\
& A_{e}=\pi\left(W_{p} L_{p} T_{p}\right)^{2 / 3} \\
& \varphi=\frac{\left(W_{p} L_{p} T_{p}\right)^{1 / 3}}{L_{p}} \\
& V_{s}=\frac{\pi D_{s}^{3}}{6} \\
& A_{s}=\pi D_{s}^{2}
\end{aligned}
$$

Images of grains with moisture contents of $0.24 \mathrm{~g} \mathrm{~g}^{-1}$ and $x^{*}$ were obtained using a Navitar ${ }^{\circledR}$ microscope $6.5 x$ coupled to a Javelin ${ }^{\circledR}$ chromachip camera equipped with a low-noise illuminator, from Cole Parmer ${ }^{\circledR}$.

\subsection{Packed bed characterization}

The bulk densities $\left(\rho_{b}\right)$ of the packed beds were obtained by measuring the sample weight and volume using a digital scale (AS 1000, Marte ${ }^{\circledR}$ ) and a graduated glass vessel with an internal diameter of $5 \mathrm{~cm}$. Small portions of particles were poured from a constant height into the glass vessel through a funnel. The vessel was tapped over a flat surface until no change was observed in the bulk volume. The mean voidages $\left(\varepsilon_{b}\right)$ were evaluated from $\rho_{a}$ and $\rho_{b}$ according to Equation 8 (Mohsenin, 1970). All measurements were made in triplicate.

$\varepsilon_{b}=1-\frac{\rho_{b}}{\rho_{a}}$

\subsection{Pressure drop measurements}

Prior to the experiments, the materials were allowed to rest at ambient temperature for $1 \mathrm{~h}$ and the assays then carried out in triplicate. The experimental set up is illustrated in Figure 2. Compressed air (1) from a blower (2) was filtered (air filter F-2000, Arprex ${ }^{\circledR}$ ) (3) and transported through a $5 \mathrm{~cm}$ diameter pipe towards the packed bed column. The air flowrate could be adjusted by a valve and was measured using a rotameter (E 9869, Gilmont ${ }^{\circledR}$ ) (4). The packed bed column was a cylindrical vessel (5) $5 \mathrm{~cm}$ in diameter $\left(D_{v}\right)$. 
The $D_{v} / D_{m}$ ratios ranged from 7.0 to 16.0 depending on the material. The particles were inserted into the column (6) to a height of $29.6 \mathrm{~cm}$, maintaining $10 \mathrm{~cm}$ of upstream and downstream stabilization sections and the packing procedure was carried out as described in section 2.3. Pressure taps (7) were placed at $5 \mathrm{~cm}$ intervals height-wise in the centre of the vessel, at a distance of $12.3 \mathrm{~cm}$ from the borders. The pressure drop $(\Delta P)$ through the packed bed was measured using a digital micromanometer (Alnor $\left.{ }^{\circledR} 530\right)(9)$ and the air temperature $\left(T_{g}\right)$ was measured using a type $\mathrm{T}$ thermocouple (8) and recorded using a Digi-Sense ${ }^{\circledR}$ digital reader $(10)$.



Figure 2. Experimental system used to measure the pressure drop in static packed beds.

The pressure drops $(\Delta P)$ were measured with different air flowrates at an average $T_{g}$ of $27^{\circ} \mathrm{C}$. The air velocity $(U)$ ranged from 0.05 to $0.58 \mathrm{~m} \mathrm{~s}^{-1}$. Each group of experiments took no more than $10 \mathrm{~min}$. The air properties $\mu$ and $\rho$ were $1.84 \times 10^{-5} \mathrm{~kg} \mathrm{~m}^{-1} \mathrm{~s}^{-1}$ and $1.18 \mathrm{~kg} \mathrm{~m}^{-3}$ (Incropera et al., 2006). The Darcy's permeability $(\kappa)$ and the inertial resistance factor $(c)$ were obtained from a linear regression of the experimental values of $\Delta P$ and $U$ in Equation 1. The parameters $\kappa$ and $c$ can be associated with the structural properties of the packed beds and particle properties by way of the Kozeny-Carman equation (Coulson \& Richardson, 2002):

$\kappa=\frac{\varepsilon_{b}^{3} d_{p}^{2} \varphi^{2}}{36 \beta\left(1-\varepsilon_{b}\right)^{2}}$

In Equation 9, $\beta$ is a shape factor and $d_{p}$ is the Sauter mean diameter. The hydraulic tortuosity $(\tau)$ was obtained from:

$\tau=\frac{\beta}{\beta_{t}}$

where $\beta_{t}$ is a factor related to the cross sectional area of the pore and is equal to 2 for circular pores (Coulson \& Richardson, 2002). The average value for the hydraulic radius $\left(R_{h}\right)$ was estimated from Equation 11 based on the values calculated for $\beta, \kappa$, and $\varepsilon_{b}$, (Scheidegger, 1974):

$R_{h}=\sqrt{\frac{\beta \kappa}{\varepsilon_{b}}}$ 


\subsection{Statistical analysis}

The influence of the moisture levels of the solids on the properties and fitted parameters was evaluated using a one-way analysis of variance (ANOVA) and Tukey's test $(p \leq 0.05)$ using the Statistica ${ }^{\circledR} 7.1$ software

In order to evaluate the differences between the experimental data $\left(y_{i}\right)$ and the data estimated by the models $\left(f\left(x_{i}\right)\right)$ used in this study, the coefficient of determination $\left(R^{2}\right)$ and root mean square error (RMSE) were calculated using Equations 12 and 13, respectively.

$$
\begin{aligned}
& R^{2}=1-\frac{\sum_{i=I}^{N}\left(y_{i}-f\left(x_{i}\right)\right)^{2}}{\sum_{i=I}^{N}\left(y_{i}-\bar{y}_{i}\right)^{2}} \\
& R M S E=\sqrt{\sum_{i=I}^{N} \frac{\left(y_{i}-f\left(x_{i}\right)\right)^{2}}{N}}
\end{aligned}
$$

\section{Results and discussion}

\subsection{Influence of the moisture content of the solids on the physical properties of the particles}

Figures 3a-h show the linear dimensions, volume, surface area, sphericity and density of the particles at different moisture levels. The dependence of the biological properties of the particles on the moisture content can be observed from these figures. Since the dimensions and shape of alumina particles do not change significantly with the moisture content, only the variation in particle density was shown for this particle (Figure 3h).

A statistically significant decrease in the linear dimensions $W_{p}, T_{p}, L_{p}$ and $D_{m}$ of the particles was observed for all the biological materials studied as the moisture content dropped (Figures 3a-d). Shrinkage is a phenomenon typically observed in food products due to the development of a pressure imbalance between the inside of the material and the external pressure (Mayor \& Sereno, 2004). Heating and water loss produce contraction stresses in cellular structures, which tend to rise as more water is removed. Therefore, shrinkage increases with the volume of water removed (Mayor \& Sereno, 2004). The linear dimensions of the lentil and barley particles were those that varied most with decreasing moisture content. Overall, all the particles showed some degree of shrinkage, as corroborated by the images depicted in Figure 4, where the biological particles at moisture levels of $0.24 \mathrm{~g} \mathrm{~g}^{-1}$ and $x^{*}$ can be compared. The different structural characteristics and internal compositions of each product offered different resistances to water motility in the solid matrixes and shrinkage showed characteristic patterns for each one (Mayor \& Sereno, 2004). The images shown in Figure 4 also illustrate the changes observed in the surface textures of the particles as the moisture content of the solids rose from $x^{*}$ to $0.24 \mathrm{~g} \mathrm{~g}^{-1}$, and surface cracking was observed in the soy, lentils and barley. Cracking appears due to uneven stresses developed during water absorption or removal (Fortes \& Okos, 1980). The oats presented no evidence of cracking or changes in the surface texture, which is probably because these particles have a quite homogeneous structure. 


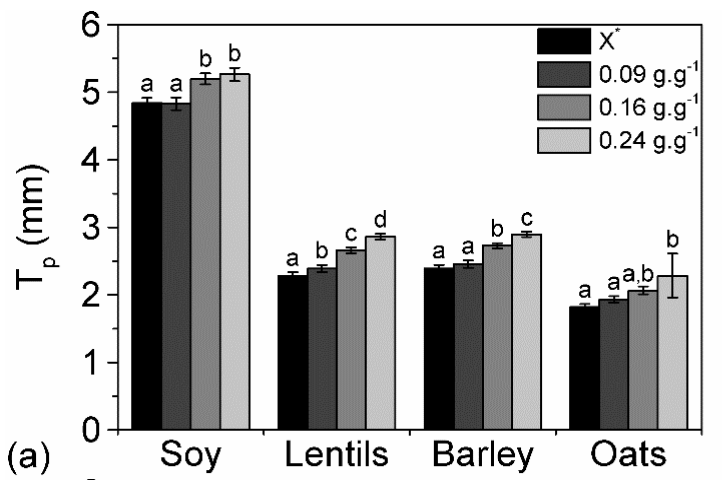

(a)
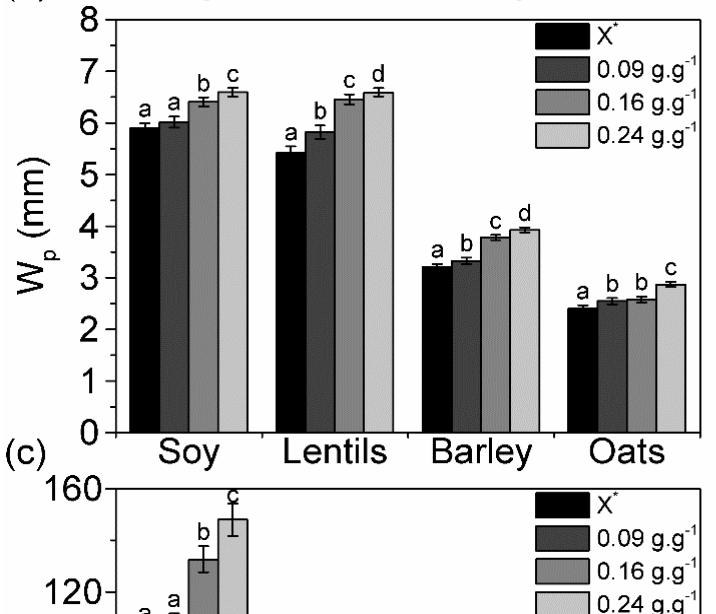

(e)

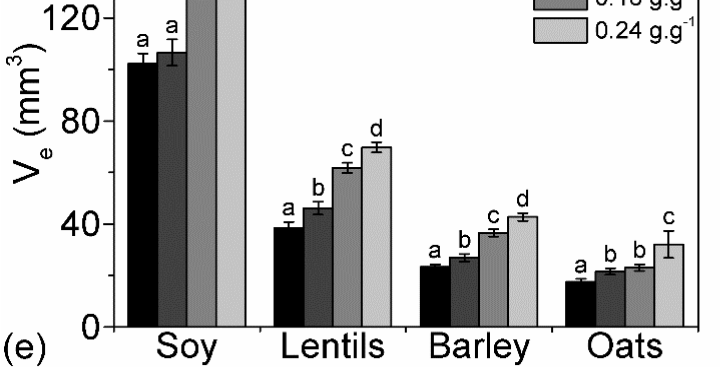

(g)

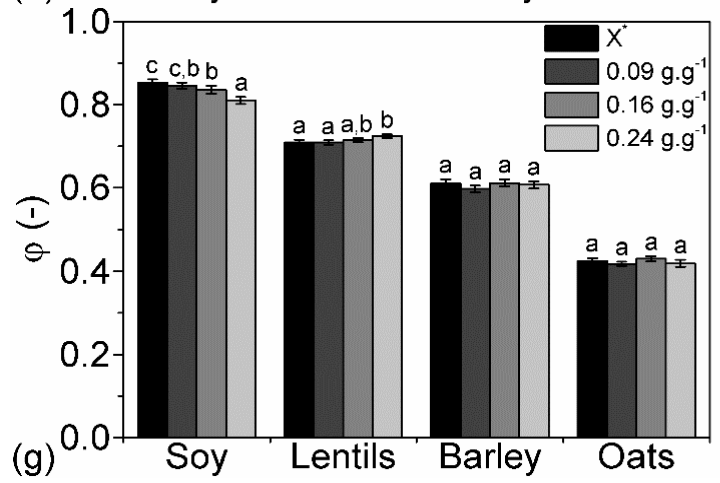

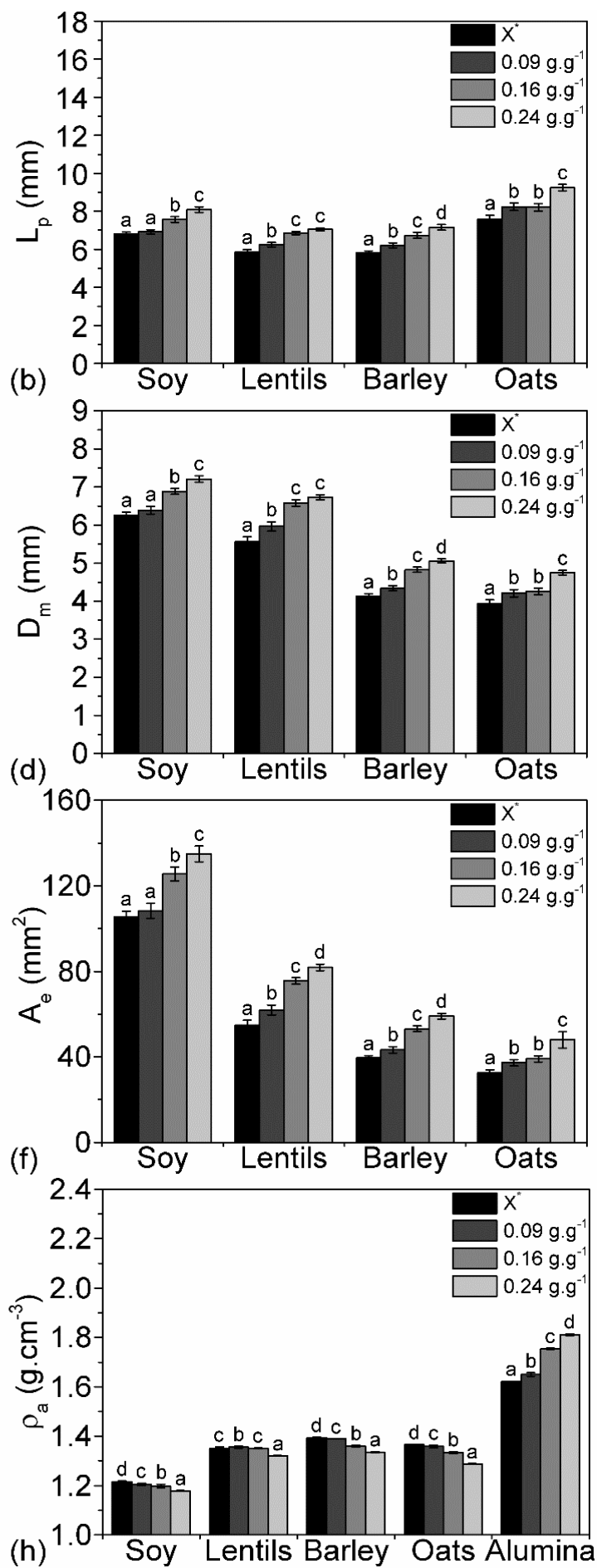

Figure 3. Influence of the moisture content of the solids on the particle properties of: thickness $\left(T_{p}\right)(\mathrm{a})$; length $\left(L_{p}\right)$ (b); width $\left(W_{p}\right)(\mathrm{c})$; mean diameter $\left(D_{m}\right)(\mathrm{d})$; volume $\left(V_{e}\right)(\mathrm{e})$; surface area $\left(A_{e}\right)(\mathrm{f})$; sphericity $(\varphi)(\mathrm{g})$; and apparent density $\left(\rho_{a}\right)(\mathrm{h})$. Values with different letters are statistically different at $p<0.05$. 
(a)

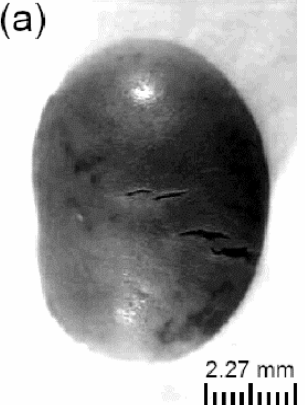

(b)

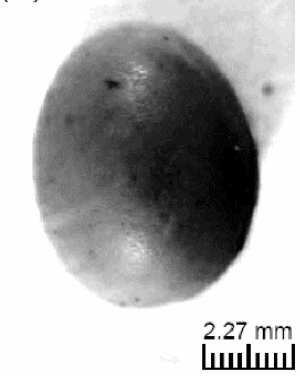

(c)

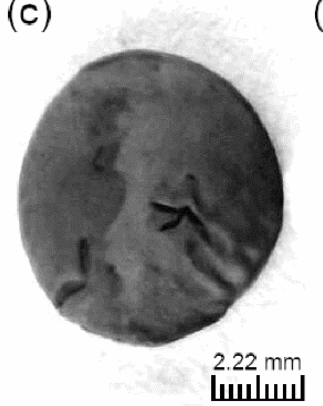

(d)

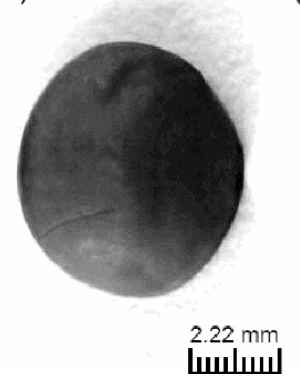

(e)

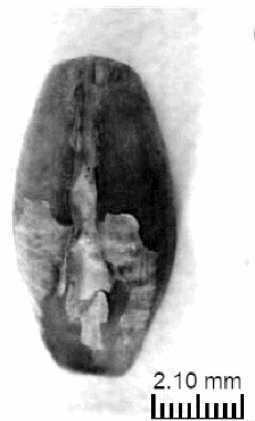

(f)

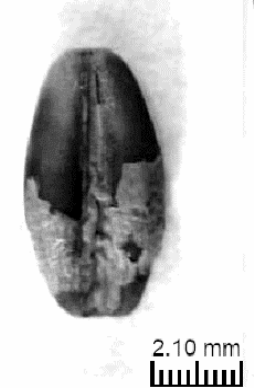

(g)

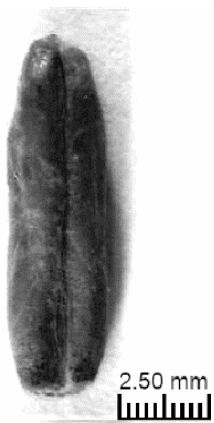

(h)

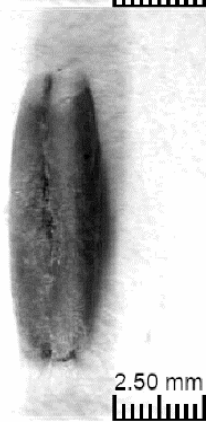

Figure 4. Influence of the moisture content of the solids on the particle surface texture: soy at $0.24 \mathrm{~g} \mathrm{~g}^{-1}$ (a) and $X^{*}$ (b), lentils at $0.24 \mathrm{~g} \mathrm{~g}^{-1}(\mathrm{c})$ and $X^{*}(\mathrm{~d})$, barley at $0.24 \mathrm{~g} \mathrm{~g}^{-1}(\mathrm{e})$ and $X^{*}(\mathrm{f})$ and oats at $0.24 \mathrm{~g} \mathrm{~g}^{-1}(\mathrm{~g})$ and $X^{*}(\mathrm{~h})$.

Based on ANOVA, in most cases it was observed that shrinkage caused a statistically significant decrease in the volume $\left(V_{e}\right)$ and surface area $\left(A_{e}\right)$ of the particles (Figures $3 \mathrm{e}$ and $3 \mathrm{f}$ ). Figures $3 \mathrm{~g}$ and 4 show that, despite significant reductions in the particle dimensions, their shape was not affected by the moisture level. According to Mayor \& Sereno (2004), in high moisture food products, shrinkage almost entirely compensates the moisture loss and the volume of the material decreases linearly with moisture content. For the grains investigated here, the linear dimensions changed proportionally and the shape was preserved. The patterns observed for the changes in sphericity and the linear dimensions of soy, lentils, barley and oats with variation in the moisture content were compatible with data previously reported for similar materials (Deshpande et al., 1993; Isik, 2007; Shah et al., 2016; Sologubik et al., 2013).

Figure $3 \mathrm{~h}$ shows that the $\rho_{a}$ of the biological particles increased as the moisture was removed. Although water removal makes particles lighter, the significant decrease observed in the particle volumes (Figure 3e) was responsible for the increase in their density. As expected, the dependence was the opposite for the alumina particles, whose $\rho_{a}$ increased as the moisture rose since moist particles are heavier and their volume is not affected by water removal.

\subsection{Influence of the moisture content of the solids on the characteristics of the packed beds}

Figures $5 \mathrm{a}$ and $5 \mathrm{~b}$ show, respectively, the values for $\rho_{b}$ and $\varepsilon_{b}$ (estimated from Equation 8) for the packed beds of grains and alumina at different moisture contents of the solids. The significant increase observed in the $\rho_{b}$ of the grains in the packed beds (Figure 5a) is consistent with the evidence that particles with lower moisture contents are denser and smaller in size. This contributes to a reduction in the interparticle void spaces and produces beds that are more compact. On the other hand, the $\rho_{b}$ of the packed beds of alumina decreased with reducing moisture content, since the water in the internal pores was gradually replaced by air and the particles became lighter, but their volume and size did not change.

Figure $5 \mathrm{~b}$ shows that the dependence of $\varepsilon_{b}$ on the moisture levels of the solids presents opposite patterns and corroborates with the idea that low-moisture grains produce beds that are more compact. The structural 
properties of the packed beds were affected by a number of factors, including the particle sizes, shapes and surface roughness (German, 1989). For the grains evaluated, the properties most affected by moisture were the particle size, surface area, volume and, to a lower degree, the surface texture. All of these played roles in the changes observed in the structural properties of the beds. In the range investigated, the $\varepsilon_{b}$ of the packed beds increased by $17.5 \%$ for lentils, $14.1 \%$ for soy, $10.2 \%$ for barley, $4.1 \%$ for alumina and $2.9 \%$ for oats. The patterns described in this section agree with those reported by researchers who investigated biological grains such as wheat, lentils and oats (Giner \& Denisienia, 1996; Kobus et al., 2011; Sokhansanj et al., 1990). No specific study on alumina was found in the literature consulted.
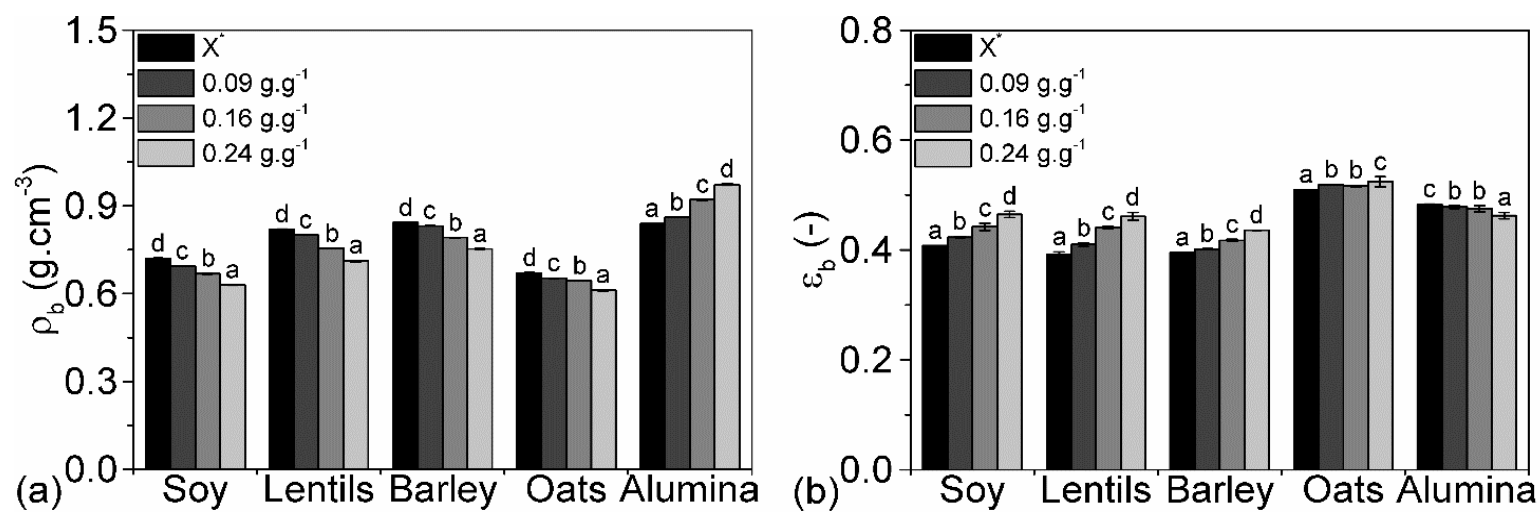

Figure 5. Influence of the moisture content of the solids on the bulk density $\left(\rho_{b}\right)$ (a) and porosity $\left(\varepsilon_{b}\right)$ (b). Values with different letters are statistically different at $p<0.05$ within the different groups.

\subsection{Influence of the moisture content of the solids on the fluid flow parameters of the packed beds}

Figure 6 shows the values of the parameters $\kappa$ and $c$ estimated by fitting the experimental data to Equation 1, as well as the packed bed properties $\tau$ and $R_{h}$, estimated from Equations 10 and 11, at the different moisture levels. 

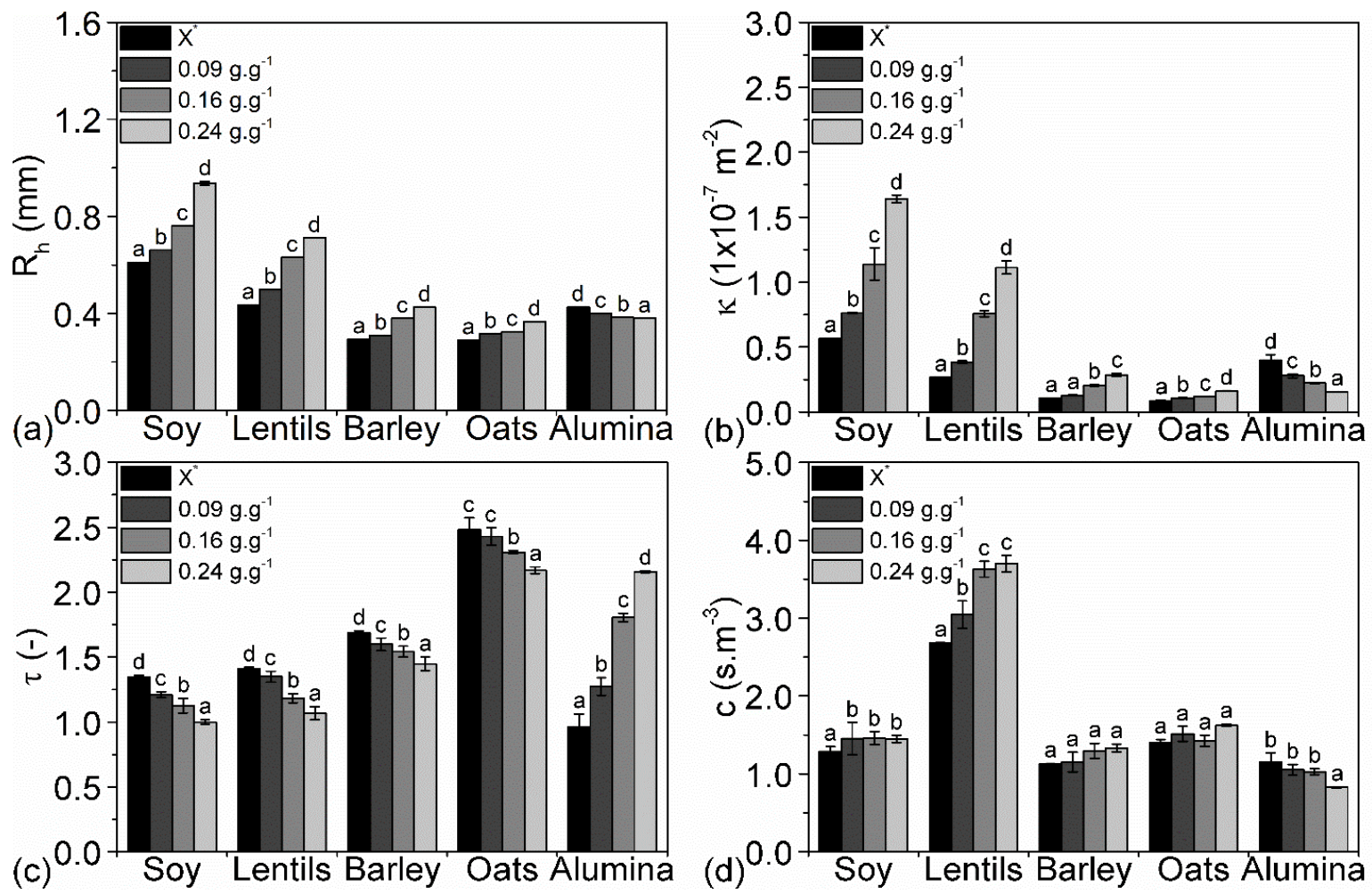

Figure 6. Influence of the moisture content of the solids on the hydraulic radius $\left(R_{h}\right)(\mathrm{a})$; permeability $(\kappa)(\mathrm{b})$; inertial resistance factor $(c)(\mathrm{c})$; and tortuosity $(\tau)(\mathrm{d})$. Values with different letters are statistically different $(p<0.05)$ within the materials.

Figures $6 \mathrm{a}$ and $6 \mathrm{~b}$ show that the values for $R_{h}$ and $\kappa$ of the grains were significantly reduced by a decrease in the moisture content, whereas alumina showed the opposite behaviour. In porous media, $R_{h}$ is a parameter related to the cross-sectional area of the capillary pores available for fluid flow. Section 3.2 demonstrated that packed beds of low-moisture grains were more compact, and therefore the patterns observed for $R_{h}$ and $\kappa$ were thoroughly consistent. The magnitudes of $R_{h}$ and $\kappa$ in the different packed beds decreased in the same order observed for $\varepsilon_{b} . R_{h}$ was reduced by $39.1 \%$ for lentils, $34.7 \%$ for soy, $30.7 \%$ for barley, $11.8 \%$ for alumina and $11.0 \%$ for oats, and $\kappa$ decreased by $76.1 \%$ for lentils, $65.6 \%$ for soy, $62.8 \%$ for barley, $61.0 \%$ for alumina and $46.8 \%$ for oats.

The values obtained for $\tau$ (Figure 6c) showed an inverse pattern to those observed for $R_{h}$ and $\kappa$. The property $\tau$ is strongly dependent on the particle shape as well as on the geometry and connectivity of the interparticle voids (German, 1989), and is higher for alumina and oats, particles whose $\varphi$ are in the upper and lower limits of the range investigated (1.0 and 0.4 respectively). As the moisture content reduced, $\tau$ increased by $55.4 \%$ for alumina, $32.2 \%$ for lentils, $24.9 \%$ for soy, $16.6 \%$ for barley and $14.5 \%$ for oats.

The variation in $c$ with moisture content (Figure 6d) was only statistically significant for soy and lentils. In flows through porous media the Reynolds number $\left(R e_{m}\right)$ (Ergun, 1952) can be evaluated from the following Equation 14:

$R e_{m}=\frac{\rho U D_{m}}{\mu\left(1-\varepsilon_{b}\right)}$

Under the conditions tested, the $R e_{m}$ ranged from 217 to 420 and, according to Bird et al. (2007), in this range both the inertial and viscous forces contribute significantly to the energy losses. The parameters associated with the energy losses in Equation 1 are $\kappa$ and $c$. In packed beds of soy, the $\kappa$ values were 
considerably higher than those of the other particles (Figure 6b), the higher values for $\varphi(>0.8)$ and $V_{e}$ possibly contributing to this result. As for parameter $c$, the highest values were found for lentils, which have a $D_{m}$ close to that of soy, but a significantly lower value for $V_{e}$ and a lower value for $\varphi$. It is worth noting that no correlation was observed between the parameters $\kappa$ and $c$ in Equation 1 and the packing properties $\tau$ or $R_{h}$.

\subsection{Influence of the moisture content of the solids on the pressure drop}

Figure 7 shows the values determined for $\Delta P / L$ in the packed beds as a function of $U$, with different moisture contents (symbols), and the values estimated from Equation 1 (lines). All the data were accurately predicted by Equation 1, as corroborated by the high values of the determination coefficient $\left(R^{2}\right)$ and relatively low values of the root-mean-square errors ( $R M S E$ ). For packed beds of grains the $\triangle P$ tends to increase at a given $U$ as the moisture content of the solids is reduced and the opposite is observed in packed beds of alumina. This behaviour is consistent with the changes observed in the structural packing properties discussed in the previous topics. In beds of grains, the increase in particle size observed as moisture is absorbed leads to beds with higher values for $\kappa$ and $R_{h}$, characteristics that favour the conductance of fluid through the pore channels and contribute to reducing the value of $\Delta P$. It is possible that the rougher surface textures observed in Figure 4 for soy, lentils and barley with high moisture contents, contribute to the rise in $\triangle P$ due to increasing losses in friction (German, 1989; Haque et al., 1982). However, since the air viscosity is low at ambient temperature, this effect is probably marginal (Górnicki \& Kaleta, 2015; Haque et al., 1982). The increase in $\triangle P$ with moisture reduction was greater in packed beds of lentils $(42.0 \%)$, soy $(41.0 \%)$ and barley (39.2\%), and more discrete in packed beds of alumina (30.1\%) and oats $(24.6 \%)$. The overall patterns found in this study agree with previous data reported for biological products (Al-Yahya \& Moghazi, 1998; Giner \& Denisienia, 1996; Górnicki \& Kaleta, 2015; Kobus et al., 2011; Molenda et al., 2005; Sokhansanj et al., 1990). 
(a)

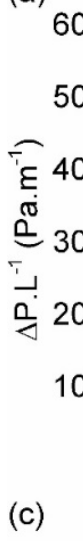
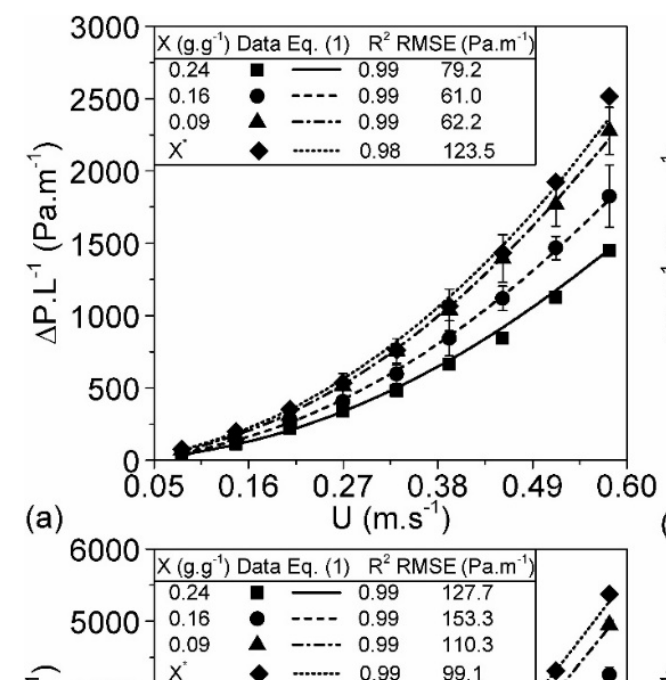

\section{(b)}

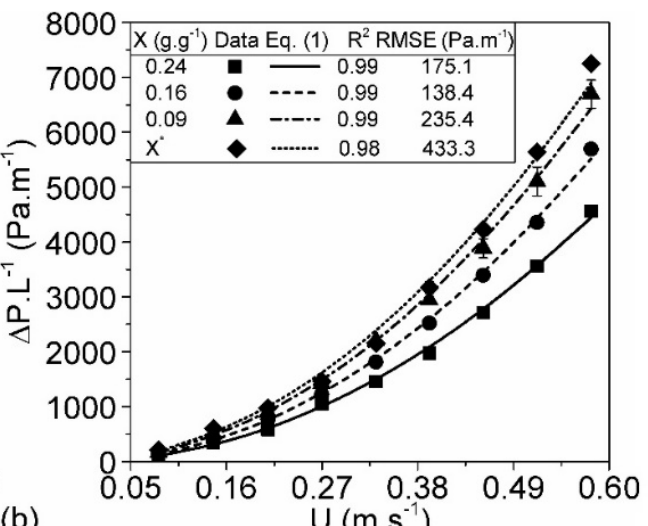

(b) 8000

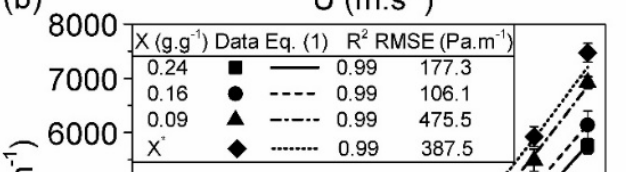

ฮั

है 5000

3000

2000

1000

(d)

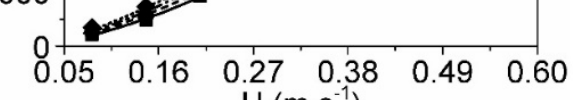

$\mathrm{U}\left(\mathrm{m} . \mathrm{s}^{-1}\right)$

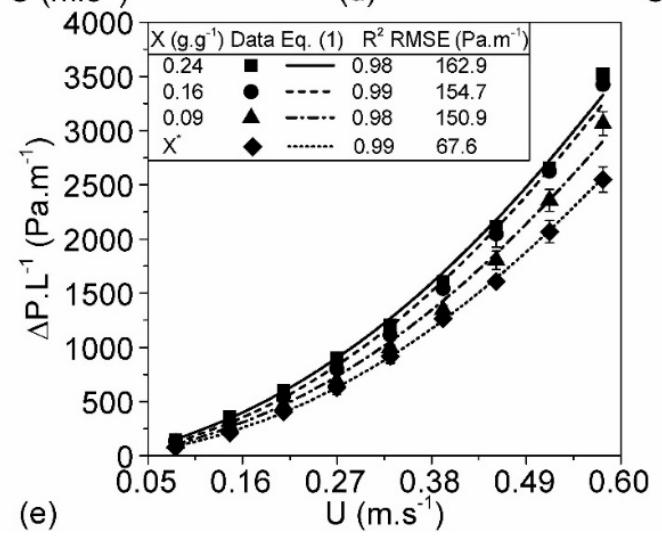

Figure 7. Pressure drop per unit length versus aeration velocity with different moisture contents; (a) soy; (b) lentils; (c) barley; (d) oats; (e) alumina.

With a view to incorporating the effect of the moisture content of the solids in Equation 1, $\kappa$ and $c$ were linearly regressed to the moisture content of the solids for each product, and the fitted equations inserted into Equation 1, resulting in a modified empirical equation, Equation 15, as follows:

$\frac{\Delta P}{L}=\frac{\mu}{A X+B} U+\frac{C X+D}{\sqrt{A X+B}} \rho U^{2}$

where $A, B, C$ and $D$ are the fitted parameters for each product. Table 1 shows the values of the fitted parameters and the statistical criteria used to evaluate the goodness of fit. It was observed that the values for $R^{2}$ were close to or equal to 1.0 and the RMSE were low, evidence of the quality of the fits. This set of equations can be used to predict the $\Delta P / L$ through static beds of grains as a function of the moisture content of the solids and aeration velocity, and provide practical and reliable estimates that are useful in the design and monitoring of grain storage in aerated silos and in static bed dryers. 
Table 1. Parameters of the particulate materials in Equation 15.

\begin{tabular}{|c|c|c|c|c|c|c|}
\hline Material & $A\left(\mathrm{~m}^{-2} \mathrm{~g}^{-1} \mathrm{~g}\right)$ & $B\left(\mathrm{~m}^{-2}\right)$ & $C\left(\mathrm{~s} \mathrm{~m}^{-3} \mathrm{~g}^{-1}\right.$ & $D\left(\mathrm{~s} \mathrm{~m}^{-3}\right)$ & $R^{2}$ & RMSE $\left(\mathrm{Pa} \mathrm{m}^{-1}\right)$ \\
\hline Soy & $5.489 \times 10^{-7}$ & $2.831 \times 10^{-8}$ & 0.654 & 1.324 & 0.99 & 62.50 \\
\hline Lentils & $4.630 \times 10^{-7}$ & $-1.909 \times 10^{-9}$ & 5.273 & 2.525 & 0.99 & 236.75 \\
\hline Barley & $9.834 \times 10^{-8}$ & $4.405 \times 10^{-9}$ & 1.178 & 1.064 & 1.00 & 82.11 \\
\hline Oats & $3.757 \times 10^{-8}$ & $6.697 \times 10^{-9}$ & 0.883 & 1.372 & 1.00 & 84.29 \\
\hline Alumina & $-1.236 \times 10^{-7}$ & $4.292 \times 10^{-8}$ & -1.648 & 1.235 & 0.98 & 125.47 \\
\hline
\end{tabular}

$A, B, C$ and $D$ are parameters in Equation 15 and $R^{2}$ is the coefficient of determination and $R M S E$ is the root mean square error.

The fitted equations were verified using experimental data reported in the literature for products and operational conditions similar to those used in the present study. Figure 8 shows a comparison of the experimental and predicted values for $\Delta P / L$ and further information on the data set used can be found elsewhere (Al-Yahya \& Moghazi, 1998; Kobus et al., 2011; Molenda et al., 2005; Sokhansanj et al., 1990). Very good agreements were observed between the experimental and predicted values for $\triangle P / L$ through packed beds of soy, lentils, barley and oats, with $R^{2}>0.9$ and low RMSE .
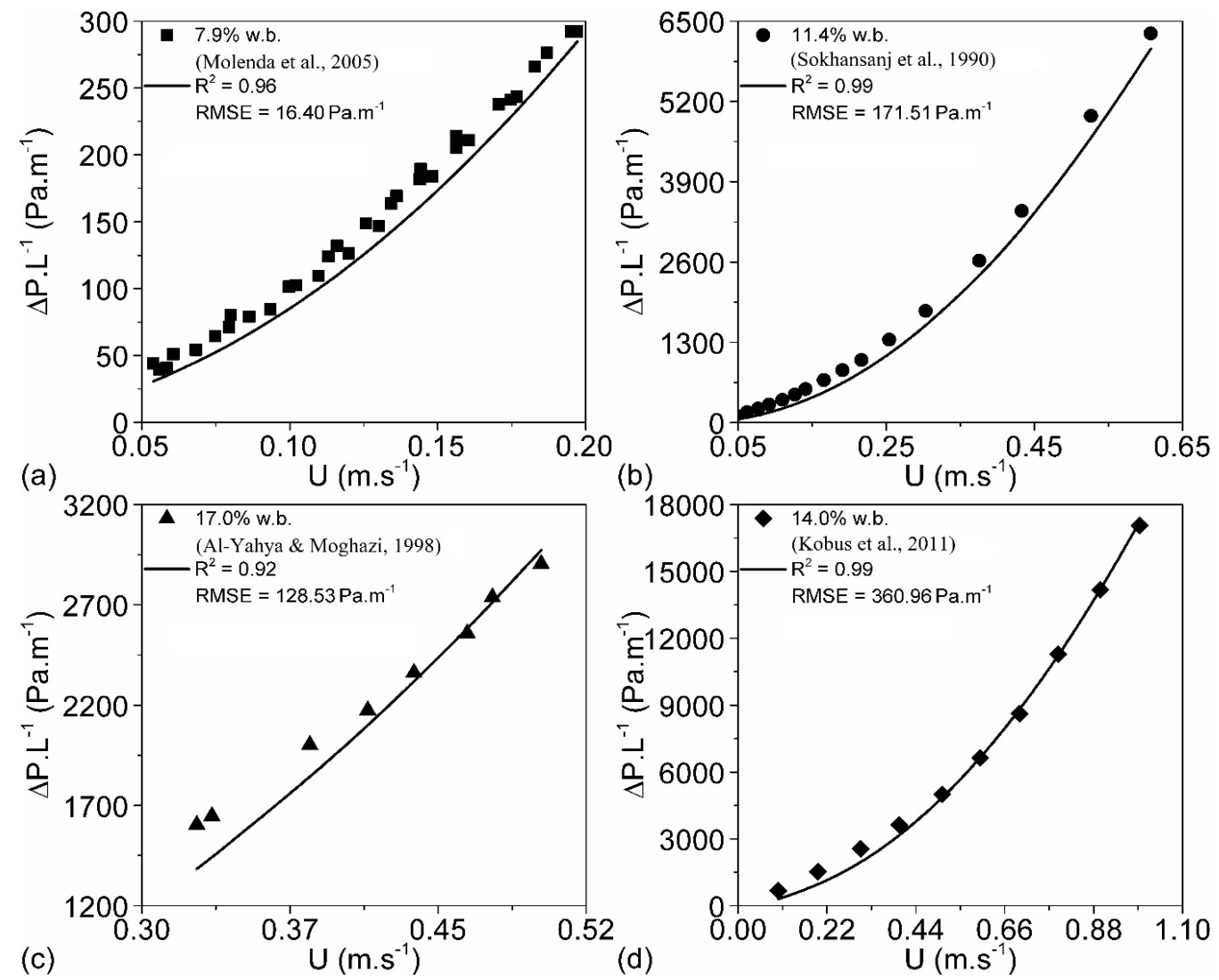

Figure 8. Predicted (Equation 15) and experimental values for $\Delta P / L$ versus aeration velocity in packed beds of biological products with different moisture contents. (a) Soy at 7.9\% w.b. (funnel); (b) lentils at $11.4 \%$ w.b. (loose fill); (c) barley at 17.0\% w.b. (bed depth of $6.2 \mathrm{~cm}$ ); (d) oats at $14.0 \%$ w.b. (0 storage day, load of $0 \mathrm{kPa}$ ). 


\section{Conclusions}

An investigation concerning the influence of the moisture content of the solids on the pressure drop through packed beds of biological particles (soy, oats, lentils and barley) was carried out for moisture levels varying from the equilibrium moisture up to $0.24 \mathrm{~g} \mathrm{~g}^{-1}$. The results demonstrated that the airflow resistance in aeration can change significantly as the moisture content of the solids decreases. As water was removed, the pressure drops increased significantly, mainly because the particle size decreased, resulting in static beds with lower bulk voidage and lower permeability. By regressing the permeability and inertial factor parameters with the moisture content, a set of simple, accurate and reliable equations could be obtained to predict the pressure drops through packed beds of biological products as a function of the moisture content of the solids.

\section{Nomenclature}

\begin{tabular}{|c|c|c|}
\hline$A$ & Empirical constant of Equation 15 & {$\left[\mathrm{~m}^{-2} \cdot \mathrm{g}^{-1} \cdot \mathrm{g}\right]$} \\
\hline$A_{e}$ & Equivalent surface area of the particle & {$\left[\mathrm{mm}^{2}\right]$} \\
\hline$A_{s}$ & Surface area of the spherical particle & {$\left[\mathrm{mm}^{2}\right]$} \\
\hline$B$ & Empirical constant of Equation 15 & {$\left[\mathrm{~m}^{-2}\right]$} \\
\hline$C$ & Empirical constant of Equation 15 & {$\left[\mathrm{~s} \mathrm{~m}^{-3} \mathrm{~g}^{-1} \mathrm{~g}\right]$} \\
\hline$c$ & Inertial resistance factor & {$\left[\mathrm{s} \mathrm{m}^{-3}\right]$} \\
\hline$D$ & Empirical constant of Equation 15 & {$\left[\mathrm{~s} \mathrm{~m}^{-3}\right]$} \\
\hline$D_{v}$ & Cylindrical vessel diameter & {$[\mathrm{cm}]$} \\
\hline$D_{m}$ & Mean diameter of the particle & {$[\mathrm{mm}]$} \\
\hline$D_{s}$ & Diameter of the spherical particle & {$[\mathrm{mm}]$} \\
\hline$d_{p}$ & Sauter mean diameter & {$[\mathrm{m}]$} \\
\hline$L$ & Distance between the pressure taps & {$[\mathrm{cm}]$} \\
\hline$L_{p}$ & Length of the particle & {$[\mathrm{mm}]$} \\
\hline$R_{h}$ & Mean hydraulic radius & {$[\mathrm{mm}]$} \\
\hline$R e_{m}$ & Reynolds number for the porous media & {$[-]$} \\
\hline$T_{p}$ & Thickness of the particle & {$[\mathrm{mm}]$} \\
\hline$T_{g}$ & Air temperature & {$\left[{ }^{\circ} \mathrm{C}\right]$} \\
\hline$U$ & Surface air velocity & {$\left[\mathrm{m} \mathrm{s}^{-1}\right]$} \\
\hline$V_{e}$ & Equivalent volume of the particle & {$\left[\mathrm{mm}^{3}\right]$} \\
\hline$V_{s}$ & Volume of the spherical particle & {$\left[\mathrm{mm}^{3}\right]$} \\
\hline$W_{p}$ & Width of the particle & {$[\mathrm{mm}]$} \\
\hline$X$ & Moisture content of the solids & {$\left[\mathrm{g} \mathrm{g}^{-1}\right]$} \\
\hline$X^{*}$ & Moisture content of the solids at equilibrium & {$\left[\mathrm{g} \mathrm{g}^{-1}\right]$} \\
\hline$\beta$ & Shape factor & {$[-]$} \\
\hline$\beta_{t}$ & Shape factor related to the cross-section of the tube & {$[-]$} \\
\hline$\varepsilon_{b}$ & Mean bulk voidage & {$[-]$} \\
\hline$\kappa$ & Permeability & {$\left[\mathrm{m}^{-2}\right]$} \\
\hline$\mu$ & Air viscosity & {$\left[\mathrm{g} \mathrm{m}^{-1} \mathrm{~s}^{-1}\right]$} \\
\hline$\rho$ & Air density & {$\left[\mathrm{g} \mathrm{m}^{-3}\right]$} \\
\hline$\rho_{a}$ & Apparent density & {$\left[\mathrm{g} \mathrm{m}^{-3}\right]$} \\
\hline$\rho_{b}$ & Bulk density & {$\left[\mathrm{g} \mathrm{m}^{-3}\right]$} \\
\hline$\varphi$ & Sphericity & {$[-]$} \\
\hline$\Delta P$ & Pressure drop & {$\left[\mathrm{g} \mathrm{m}^{-1} \mathrm{~s}^{-2}\right]$} \\
\hline
\end{tabular}




\section{Acknowledgements}

The authors are grateful to the National Council for Scientific and Technological Development (CNPq) and to the Coordination for Improvement of High Personnel Education (CAPES), for their financial support of this research.

\section{References}

Al-Yahya, S. A., \& Moghazi, H. M. M. (1998). Static pressure drop through barley grain. Canadian Agricultural Engineering, 16(1), 223-239.

Bala, B. K. (2016). Drying and storage of cereal grains. Chichester: John Wiley \& Sons. http://dx.doi.org/10.1002/9781119124207.

Bird, R. B., Stewart, W. E., \& Lightfoot, E. N. (2007). Transport phenomena. Chichester: John Wiley \& Sons.

Coulson, J. M., \& Richardson, J. F. (2002). Chemical engineering: Particle technology and separation processes. Oxford: Butterworth Heinemann.

Cruz, R. B., Guerra, D. R. S., \& Azevedo, T. L. (2014). Evaluation of pressure drop in flow over fixed porous bed. Engenharia Térmica, 13(1), 42-47. http://dx.doi.org/10.5380/reterm.v13i1.62068

Deshpande, S. D., Bal, S., \& Ojha, T. P. (1993). Physical properties of soybean. Journal of Agricultural Engineering Research, 56(2), 89-98. http://dx.doi.org/10.1006/jaer.1993.1063

Ergun, S. (1952). Fluid flow through packed columns. Chemical Engineering Progress, 48, 89-94.

Felizardo, M. P., \& Freire, J. T. (2018). Characterization of barley grains in different levels of pearling process. Journal of Food Engineering, 232, 29-35. http://dx.doi.org/10.1016/j.jfoodeng.2018.03.017

Food and Agriculture Organization of the United Nations - FAO. (2018). World food situation. Rome: FAO. Retrieved in 2018, August 30, from http://www.fao.org/worldfoodsituation/csdb/en/

Fortes, M., \& Okos, M. R. (1980). Changes in physical properties of corn during drying. Transactions of the ASAE. American Society of Agricultural Engineers, 23(4), 1004-1008. http://dx.doi.org/10.13031/2013.34705

German, R. M. (1989) Particle paking characteristics. Princeton: MPIF.

Giner, S. A., \& Denisienia, E. (1996). Pressure drop through wheat as affected by air velocity, moisture content and fines. Journal of Agricultural Engineering Research, 63(1), 73-86. http://dx.doi.org/10.1006/jaer.1996.0009

Górnicki, K., \& Kaleta, A. (2015). Resistance of bulk grain to air flow: A review. Part II. Annals of Warsaw University of Life Sciences, 65, 43-51.

Haque, E., Ahmed, Y. N., \& Deyoe, C. W. (1982). Static pressure drop in a fixed bed of grain as affected by grain moisture content. Transactions of the ASAE. American Society of Agricultural Engineers, 25(4), 1095-1098. http://dx.doi.org/10.13031/2013.33675

Incropera, F. P., Dewitt, D. P., Bergman, T. L., \& Lavine, A. S. (2006). Fundamentals of heat and mass transfer (6th ed.). New York: John Wiley \& Sons.

Isik, E. (2007). Moisture dependent physical and mechanical properties of green laird lentil (Lens culinaris) grains. Pakistan Journal of Biological Sciences, 10(3), 474-480. PMid:19069520. http://dx.doi.org/10.3923/pjbs.2007.474.480

Khatchatourian, O. A., \& Savicki, D. L. (2004). Mathematical modelling of airflow in an aerated soya bean store under nonuniform conditions. Biosystems Engineering, 88(2), 201-211. http://dx.doi.org/10.1016/j.biosystemseng.2004.03.001

Khatchatourian, O. A., Binelo, M. O., Neutzling, R., \& Faoro, V. (2017). Models to predict the thermal state of rice stored in aerated vertical silos. Biosystems Engineering, 161, 14-23. http://dx.doi.org/10.1016/j.biosystemseng.2017.06.013

Kobus, Z., Guz, T., \& Nadulski, R. (2011). Influence of moisture and vertical pressure on air flow resistance through oat grain. Agricultural Engineering, 7(132), 29-35.

Li, W., \& Sokhansanj, S. (1994). Generalized equation for airflow resistance of bulk grains with variable density, moisture content and fines. Drying Technology, 12(3), 649-667. http://dx.doi.org/10.1080/07373939408959982

Matthies, H. J., \& Petersen, H. (1974). New data for calculating the resistance to air flow of stored granular materials. Transactions of the ASAE, 17(6), 1144-1149. http://dx.doi.org/10.13031/2013.37048

Mayor, L., \& Sereno, A. M. (2004). Modelling shrinkage during convective drying of food materials: A review. Journal of Food Engineering, 61(3), 373-386. http://dx.doi.org/10.1016/S0260-8774(03)00144-4

Mohsenin, N. (1970). Physical properties of plant and animal materials. New York: Gordon and Breach.

Molenda, M., Montross, M. D., McNeill, S. G., \& Horabik, J. (2005). Airflow resistance of seeds at different bulk densities using Ergun's equation. Transactions of the ASAE, 48(3), 1137-1145. http://dx.doi.org/10.13031/2013.18487

Park, J. H., Lee, M., Moriyama, K., Kim, M. H., Kim, E., \& Park, H. S. (2018). Adequacy of effective diameter in predicting pressure gradients of air flow trhough packed beds with particle size distribution. Annals of Nuclear Energy, 112, 769-778. http://dx.doi.org/10.1016/j.anucene.2017.08.053 
Prediction of pressure drop through packed beds of granular materials: influence of moisture reduction and air velocity Altino, H. O. N., \& Ferreira, M. C.

Rabello, T. (2018, november 21). Os gargalos de sempre: Agora vai? Summit Agronegócio Brasil 2018. Estadão. Retrieved in 2018, December 18, from https://infograficos.estadao.com.br/economia/summit/2018/desafios/

Scheidegger, A. E. (1974). The physics of flow through porous media. Toronto: University of Toronto Press.

Shah, A., Masoodi, F. A., Gani, A., \& Ashwar, B. A. (2016). Geometrical, functional, thermal, and structural properties of oat varieties from temperate region of India. Journal of Food Science and Technology, 53(4), 1856-1866. PMid:27413212. http://dx.doi.org/10.1007/s13197-015-2119-2

Shedd, C. K. (1953). Resistance of grains and seeds to air flow. Agricultural Engineering, 34(9), 616-619.

Sokhansanj, S., Falacinski, A. A., Sosulski, R. W., Jayas, D. S., \& Tang, J. (1990). Resistance of bulk lentils to airflow. Transactions of the ASAE, 33(4), 1281-1285. http://dx.doi.org/10.13031/2013.31469

Sologubik, C. A., Campañone, L. A., Pagano, A. M., \& Gely, M. C. (2013). Effect of moisture content on some physical properties of barley. Industrial Crops and Products, 43(1), 762-767. http://dx.doi.org/10.1016/j.indcrop.2012.08.019

Yang, X., \& Williams, D. L. (1990). Airflow resistance of grain sorghum as affected by bulk density. Transactions of the ASAE, 33(6), 1966-1970. http://dx.doi.org/10.13031/2013.31565

Received: Sept. 10, 2018; Accepted: Apr. 27, 2019 